\title{
Cancer incidence and mortality in relation to body mass index in the Million Women Study: cohort study
}

\author{
Gillian K Reeves, statistical epidemiologist, ${ }^{1}$ Kirstin Pirie, statistician,, ${ }^{1}$ Valerie Beral, director, ${ }^{1}$ \\ Jane Green, clinical research scientist, ${ }^{1}$ Elizabeth Spencer, nutritionist, ${ }^{1}$ Diana Bull, senior statistician, ${ }^{1}$ for the \\ Million Women Study Collaborators
}

Cancer Epidemiology Unit,

University of Oxford,

Oxford OX3 7LF

Correspondence to: $\mathrm{G}$ Reeves

gill.reeves@ceu.ox.ac.uk

doi:10.1136/bmj.39367.495995.AE

\section{ABSTRACT}

Objective To examine the relation between body mass index $\left(\mathrm{kg} / \mathrm{m}^{2}\right)$ and cancer incidence and mortality.

Design Prospective cohort study.

Participants 1.2 million UK women recruited into the Million Women Study, aged 50-64 during 1996-2001, and followed up, on average, for 5.4 years for cancer incidence and 7.0 years for cancer mortality.

Main outcome measures Relative risks of incidence and mortality for all cancers, and for 17 specific types of cancer, according to body mass index, adjusted for age, geographical region, socioeconomic status, age at first birth, parity, smoking status, alcohol intake, physical activity, years since menopause, and use of hormone replacement therapy.

Results 45037 incident cancers and 17203 deaths from cancer occurred over the follow-up period. Increasing body mass index was associated with an increased incidence of endometrial cancer (trend in relative risk per 10 units $=2.89,95 \%$ confidence interval 2.62 to 3.18 ), adenocarcinoma of the oesophagus $(2.38,1.59$ to 3.56$)$, kidney cancer $(1.53,1.27$ to 1.84$)$, leukaemia $(1.50,1.23$ to 1.83$)$, multiple myeloma (1.31, 1.04 to 1.65$)$, pancreatic cancer (1.24, 1.03 to 1.48$)$, non-Hodgkin's lymphoma (1.17, 1.03 to 1.34$)$, ovarian cancer $(1.14,1.03$ to 1.27$)$, all cancers combined $(1.12,1.09$ to 1.14$)$, breast cancer in postmenopausal women $(1.40,1.31$ to 1.49$)$ and colorectal cancer in premenopausal women $(1.61,1.05$ to 2.48 ). In general, the relation between body mass index and mortality was similar to that for incidence. For colorectal cancer, malignant melanoma, breast cancer, and endometrial cancer, the effect of body mass index on risk differed significantly according to menopausal status.

Conclusions Increasing body mass index is associated with a significant increase in the risk of cancer for 10 out of 17 specific types examined. Among postmenopausal women in the UK, $5 \%$ of all cancers (about 6000 annually) are attributable to being overweight or obese. For endometrial cancer and adenocarcinoma of the oesophagus, body mass index represents a major modifiable risk factor; about half of all cases in postmenopausal women are attributable to overweight or obesity.

\section{INTRODUCTION}

The prevalence of obesity has been increasing in developed countries, ${ }^{1}$ and national survey data from the United Kingdom indicate that around 23\% of all women in England are obese and 34\% are overweight. $^{2}$ Obesity is known to be associated with excess mortality from all causes combined, ${ }^{3-5}$ but less is known about its effects on cancer. In particular, although it is widely accepted that body mass index (BMI) is positively associated with cancers of the colon, endometrium, and kidney, adenocarcinoma of the oesophagus, and postmenopausal breast cancer, ${ }^{6}$ the magnitudes of such effects and the role of BMI in the development of other, rarer, cancers are less certain. Furthermore, body mass index may affect not only the development of certain cancers but also the subsequent risk of death. ${ }^{7}$ Examining the effect of $\mathrm{BMI}$ on both incidence and mortality within the same population is therefore important. We report here on the risk of incident and fatal cancer for a wide range of malignancies according to BMI among women in the Million Women Study, a large cohort study of women in the UK.

\section{METHODS}

Data collection, follow-up, and definitions

In 1996-2001 a total of 1.3 million women aged 50-64 who had been invited for screening for breast cancer at screening centres throughout England and Scotland completed the first study questionnaire, which asked about height, weight, social and demographic factors, and other personal characteristics. The cohort was resurveyed about three years after recruitment to update information on various factors, including weight. Full details of the study design and methods are described elsewhere ${ }^{8}$ and both questionnaires can be viewed at www.millionwomenstudy.org. Study participants have been flagged on the National Health Service central registers, so that cancer registrations and deaths are routinely notified to the study investigators. This information includes the date of each such event and codes the site and morphology of the cancer according to the ICD-10 (international classification of diseases, 10th revision). All participants gave their written consent to take part in the study. 
At recruitment, we asked women for their current weight and height and then used these variables to derive body mass index (weight $(\mathrm{kg}) /$ height $\left.(\mathrm{m})^{2}\right)$, which we categorised as follows: less than 22.5, 22.5-24.9, 25.0-27.4, 27.5-29.9, and 30 or more. In all analyses, we chose the BMI category of 22.5-24.9 as the reference group. We defined women with a BMI of 25-29.9 as "overweight" and women with a BMI of 30 or more as "obese," in accordance with the World Health Organization's criteria. ${ }^{9}$

We examined incidence of and mortality from cancer in relation to BMI for all cancers combined (except non-melanoma skin cancer) and for 17 of the most common cancer sites or types of cancer. As some evidence exists to show that adenocarcinoma of the oesophagus may be more strongly related to BMI than squamous cell carcinoma of the oesophagus, ${ }^{6}$ we subdivided oesophageal cancers into these two histological types on the basis of ICD-10 morphology codes. Similarly, because the effect of BMI on the risk of breast cancer is known to vary according to menopausal status and use of hormone replacement therapy, ${ }^{6}$ we did separate analyses with respect to breast cancer for premenopausal women and postmenopausal women who had never used hormone replacement therapy.

\section{Statistical analysis}

We excluded women diagnosed before recruitment as having any cancer other than non-melanoma skin cancer (C44), or for whom height, weight, or both were unknown, from all analyses. In analyses of cancer incidence, eligible women contributed person years from the date of recruitment until the date of registration with the cancer of interest, date of death, or end of follow-up, whichever was the earliest. In addition, women diagnosed with any cancer other than the cancer of interest (except non-melanoma skin cancer) during the follow-up period were censored at the date of diagnosis of that cancer. The end of follow-up for cancer incidence was 31 December 2004 for all registries except Trent and North Yorkshire, Northwest, and Scotland, for which the corresponding dates were 30 June 2004, 31 December 2003, and 31 December 1999. For analyses of cancer mortality, eligible women contributed person years from recruitment until death from the cancer of interest, death from some other cause, or end of follow-up, whichever was the earliest. The end of follow-up for cancer mortality was 31 December 2005.

We considered each of the cancer sites of interest as an end point in a proportional hazards model with body mass index included as a categorical variable and attained age as the underlying time variable. We stratified analyses by broad geographical region (10 regions corresponding to the areas covered by the cancer registries) and fifths of socioeconomic status based on deprivation index, ${ }^{10}$ and we made adjustments for age at first birth $(<20,20-24,25-29, \geq 30)$, parity $(0,1,2,3, \geq 4)$, smoking status (never, past, current $<10$ cigarettes/day, current 10-19 cigarettes/day, current $\geq 20$ cigarettes/day), average daily alcohol intake in drinks per day $(0,1,2, \geq 3)$, physical activity (rarely/never, $\leq$ once a week, >once a week) and, where appropriate, years since menopause (premenopausal, perimenopausal, $<5, \geq 5$ ) and use of hormone replacement therapy (current, past, never). Unless otherwise specified, we derived all variables included in the model from information reported at recruitment. We confined analyses of endometrial and cervix cancer to women who reported never having had a hysterectomy and analyses of ovarian cancer to women who reported not having had a bilateral oophorectomy before recruitment. We assigned women with missing

Table 1 Characteristics of the study population at recruitment, and details of follow-up, according to body mass index. Values are percentages (numbers) unless stated otherwise

\begin{tabular}{|c|c|c|c|c|}
\hline \multirow[b]{2}{*}{ Characteristics } & \multicolumn{3}{|c|}{ Body mass index $(\mathrm{kg} / \mathrm{m} 2)$} & \multirow[b]{2}{*}{ All women } \\
\hline & $<25$ & $25-29$ & $\geq 30$ & \\
\hline No of women & 566738 & 436183 & 219709 & 1222630 \\
\hline Median (interquartile range) body mass index & $22.9(21.5-23.9)$ & $27.0(25.9-28.2)$ & $32.9(31.1-35.7)$ & $25.4(23.0-28.6)$ \\
\hline Mean (SD) age (years) & $55.7(4.4)$ & $56.1(4.4)$ & $56.0(4.4)$ & $55.9(4.4)$ \\
\hline Upper third of socioeconomic group & $36(206743)$ & $32(141598)$ & $26(57226)$ & $33(405567)$ \\
\hline Mean (SD) No of children & $2.0(1.2)$ & $2.2(1.2)$ & $2.3(1.4)$ & $2.1(1.2)$ \\
\hline Mean (SD) age at first birth (years) & $24.2(4.3)$ & $23.7(4.2)$ & $23.2(4.3)$ & $23.8(4.3)$ \\
\hline Strenuous physical activity more than once a week & $25(138817)$ & $19(82030)$ & $14(29950)$ & $21(250797)$ \\
\hline Mean (SD) alcohol intake (g/day) & $5.6(6.3)$ & $4.9(6.0)$ & $3.7(5.4)$ & $5.0(6.1)$ \\
\hline Current smoker & $22(122834)$ & $18(80058)$ & $16(34$ 196) & $19(237088)$ \\
\hline Current user of hormone replacement therapy & $37(206861)$ & $33(143542)$ & $28(61176)$ & $34(411579)$ \\
\hline Hysterectomy & $22(126056)$ & $26(114714)$ & $28(61870)$ & $25(302640)$ \\
\hline \multicolumn{5}{|l|}{ Follow-up } \\
\hline Woman years of follow-up for incidence (1000s) & 3014 & 2276 & 1129 & 6419 \\
\hline Total No of incident cancers & 20600 & 15890 & 8547 & 45037 \\
\hline Woman years of follow-up for death (1000s) & 3976 & 3041 & 1518 & 8536 \\
\hline Total No of cancer deaths & 7812 & 5952 & 3439 & 17203 \\
\hline
\end{tabular}


values for any of the adjustment variables to a separate category for that variable. We also examined the effect of restricting analyses to women with known values for all adjustment variables and of varying the level of adjustment for certain factors.

We summarised the relation between BMI and incidence for each cancer site or type in the form of a loglinear trend in risk per 10 unit increase in BMI (broadly equivalent to the difference in median BMI among obese women compared with women in the reference category of 22.5-24.9). We did various sensitivity analyses to assess the robustness of these summary estimates under relevant restrictions. Updated information on body mass index from the follow-up questionnaire was available for $450186(36.8 \%)$ of the women included in these analyses. We therefore did additional analyses using this updated information to estimate median values of BMI within categories defined by BMI at recruitment, to allow for potential regression dilution. ${ }^{11} \mathrm{We}$ also repeated analyses separately for women defined as premenopausal at recruitment and for women defined at recruitment as postmenopausal and never having used hormone replacement therapy, for those sites with more than 50 cases among premenopausal women.

As the analyses presented here generally involve comparison of risks across more than two categories, variances are, where appropriate, estimated by treating the relative risks as floating absolute risks. ${ }^{12}$ Results according to BMI category are, therefore, presented in the form of plots of relative risks and their corresponding floated confidence intervals. The position

\begin{tabular}{|c|c|c|c|c|c|c|c|}
\hline \multirow[b]{2}{*}{ Site (ICD-10 code) } & \multirow[b]{2}{*}{$\begin{array}{l}\text { No of } \\
\text { cases }\end{array}$} & \multicolumn{5}{|c|}{ FAR $(95 \% \mathrm{FCl})$ for incidence in women with body mass index $(\mathrm{kg} / \mathrm{m} 2)$} & \multirow[b]{2}{*}{$\begin{array}{l}\text { Trend }(95 \% \mathrm{Cl}) \\
\text { per } 10 \text { units }\end{array}$} \\
\hline & & $<22.5$ & $\begin{array}{c}22.5-24.9 \\
\text { (reference group) }\end{array}$ & $25-27.4$ & $27.5-29.5$ & $\geq 30$ & \\
\hline $\begin{array}{l}\text { Adenocarcinoma of } \\
\text { oesophagust (C15) }\end{array}$ & 150 & $\begin{array}{c}1.06(0.70 \text { to } 1.62) \\
(n=22)\end{array}$ & $1.00(0.68$ to 1.46$)(n=27)$ & $\begin{array}{c}1.28(0.90 \text { to } 1.83) \\
(n=30)\end{array}$ & $\begin{array}{c}1.57\left(\begin{array}{c}(1.04 \text { to } 2.36) \\
(n=23)\end{array}\right.\end{array}$ & $\begin{array}{c}2.54(1.89 \text { to } 3.41) \\
(n=48)\end{array}$ & 2.38 (1.59 to 3.56$)$ \\
\hline $\begin{array}{l}\text { Squamous cell carcinoma } \\
\text { of oesophagus } \ddagger \text { (C15) }\end{array}$ & 263 & $\begin{array}{c}2.04 \begin{array}{c}(1.67 \text { to } 2.48) \\
(n=106)\end{array}\end{array}$ & $1.00(0.78$ to 1.28$)(n=63)$ & $\begin{array}{c}0.96(0.73 \text { to } 1.26) \\
(n=52)\end{array}$ & $\begin{array}{c}0.61(0.40 \text { to } 0.94) \\
(n=21)\end{array}$ & $\begin{array}{c}0.47(0.31 \text { to } 0.73) \\
(n=21)\end{array}$ & $0.26(0.18$ to 0.38$)$ \\
\hline Stomach (C16) & 521 & $\begin{array}{c}1.26(1.05 \text { to } 1.51) \\
(n=117)\end{array}$ & $1.00(0.84$ to 1.20$)(n=121)$ & $\begin{array}{c}1.04(0.86 \text { to } 1.25) \\
(n=111)\end{array}$ & $\begin{array}{c}1.10(0.88 \text { to } 1.38) \\
(n=76)\end{array}$ & $\begin{array}{c}1.04(0.84 \text { to } 1.27) \\
(n=96)\end{array}$ & $0.90(0.72$ to 1.13$)$ \\
\hline Colorectum (C18-C20) & 4008 & $\begin{array}{c}1.02(0.95 \text { to } 1.10) \\
(n=789)\end{array}$ & $1.00(0.94$ to 1.06$)(n=1034)$ & $\begin{array}{c}1.04(0.97 \text { to } 1.11) \\
(n=913)\end{array}$ & $\begin{array}{c}1.01\left(\begin{array}{c}(0.93 \text { to } 1.10) \\
(n=555)\end{array}\right.\end{array}$ & $\begin{array}{c}1.01 \text { ( } 0.94 \text { to } 1.09) \\
(n=717)\end{array}$ & $1.00(0.92$ to 1.08$)$ \\
\hline Pancreas (C25) & 795 & $\begin{array}{c}1.15(0.98 \text { to } 1.34) \\
(n=166)\end{array}$ & $1.00(0.86$ to 1.16$)(n=184)$ & $\begin{array}{c}1.02(0.88 \text { to } 1.19) \\
(n=160)\end{array}$ & $\begin{array}{c}1.20 \begin{array}{c}(1.00 \text { to } 1.44) \\
(n=116)\end{array}\end{array}$ & $\begin{array}{c}1.37 \begin{array}{c}(1.18 \text { to } 1.60) \\
(n=169)\end{array}\end{array}$ & 1.24 (1.03 to 1.48$)$ \\
\hline Lung (C34) & 3171 & $\begin{array}{c}1.17 \begin{array}{c}(1.09 \text { to } 1.25) \\
(n=828)\end{array}\end{array}$ & $1.00(0.93$ to 1.07$)(n=823)$ & $\begin{array}{c}0.91(0.85 \text { to } 0.99) \\
(n=653)\end{array}$ & $\begin{array}{c}0.83\left(\begin{array}{c}(0.75 \text { to } 0.91) \\
(n=376)\end{array}\right.\end{array}$ & $\begin{array}{c}0.84 \begin{array}{c}(0.77 \text { to } 0.92) \\
(n=491)\end{array}\end{array}$ & $0.74(0.67$ to 0.82$)$ \\
\hline $\begin{array}{l}\text { Malignant melanoma } \\
\text { (C43) }\end{array}$ & 1635 & $\begin{array}{c}1.00(0.90 \text { to } 1.11) \\
(n=346)\end{array}$ & $1.00(0.91$ to 1.10$)(n=456)$ & $\begin{array}{c}1.05(0.95 \text { to } 1.16) \\
(n=384)\end{array}$ & $\begin{array}{c}0.91 \text { (0.79 to } 1.05) \\
(n=198)\end{array}$ & $\begin{array}{c}0.94(0.83 \text { to } 1.07) \\
(n=251)\end{array}$ & $0.94(0.82$ to 1.07$)$ \\
\hline $\begin{array}{l}\text { Premenopausal breast } \\
\text { (C50) }\end{array}$ & 1179 & $\begin{array}{c}0.96(0.85 \text { to } 1.08) \\
(n=271)\end{array}$ & $1.00(0.90$ to 1.11$)(n=352)$ & $\begin{array}{c}0.93(0.82 \text { to } 1.05) \\
(n=239)\end{array}$ & $\begin{array}{c}0.99 \begin{array}{l}(0.84 \text { to } 1.16) \\
(n=151)\end{array}\end{array}$ & $\begin{array}{c}0.79(0.68 \text { to } 0.92) \\
(n=166)\end{array}$ & $0.86(0.73$ to 1.00$)$ \\
\hline $\begin{array}{l}\text { Postmenopausal breast§ } \\
\text { (C50) }\end{array}$ & 5629 & $\begin{array}{c}0.85(0.80 \text { to } 0.91) \\
(n=879)\end{array}$ & $1.00(0.95$ to 1.06$)(n=1336)$ & $\begin{array}{c}1.10(1.04 \text { to } 1.16) \\
(n=1262)\end{array}$ & $\begin{array}{c}1.21 \begin{array}{c}(1.13 \text { to } 1.29) \\
(n=878)\end{array}\end{array}$ & $\begin{array}{c}1.29(1.22 \text { to } 1.36) \\
(n=1274)\end{array}$ & $1.40(1.31$ to 1.49$)$ \\
\hline Cervix (C53) & 330 & $\begin{array}{c}0.90(0.70 \text { to } 1.15) \\
(n=66)\end{array}$ & $1.00(0.81$ to 1.23$)(n=90)$ & $\begin{array}{c}0.94(0.75 \text { to } 1.19) \\
(n=71)\end{array}$ & $\begin{array}{c}0.79(0.57 \text { to } 1.10) \\
(n=37)\end{array}$ & $\begin{array}{c}1.02(0.80 \text { to } 1.31) \\
(n=66)\end{array}$ & 1.04 (0.79 to 1.38$)$ \\
\hline Endometrium (C54) & 2657 & $\begin{array}{c}0.84 \begin{array}{c}(0.75 \text { to } 0.93) \\
(n=340)\end{array}\end{array}$ & $1.00(0.92$ to 1.09$)(n=524)$ & $\begin{array}{c}1.21\left(\begin{array}{c}(1.11 \text { to } 1.32) \\
(n=516)\end{array}\right.\end{array}$ & $\begin{array}{c}1.43(1.29 \text { to } 1.58) \\
(n=366)\end{array}$ & $\begin{array}{c}2.73 \begin{array}{c}(2.55 \text { to } 2.92) \\
(n=911)\end{array}\end{array}$ & 2.89 (2.62 to 3.18$)$ \\
\hline Ovary (C56) & 2406 & $\begin{array}{c}0.98(0.89 \text { to } 1.07) \\
(n=478)\end{array}$ & $1.00(0.92$ to 1.08$)(n=631)$ & $\begin{array}{c}0.99 \begin{array}{c}(0.91 \text { to } 1.08) \\
(n=510)\end{array}\end{array}$ & $\begin{array}{c}1.13\left(\begin{array}{c}1.02 \text { to } 1.25) \\
(n=349)\end{array}\right.\end{array}$ & $\begin{array}{c}1.12(1.02 \text { to } 1.23) \\
(n=438)\end{array}$ & $1.14(1.03$ to 1.27$)$ \\
\hline Kidney (C64) & 723 & $\begin{array}{c}0.95(0.79 \text { to } 1.14) \\
(n=119)\end{array}$ & $1.00(0.86$ to 1.17$)(n=165)$ & $\begin{array}{c}1.10(0.94 \text { to } 1.28) \\
(n=155)\end{array}$ & $\begin{array}{c}1.19 \begin{array}{c}(0.99 \text { to } 1.44) \\
(n=106)\end{array}\end{array}$ & $\begin{array}{c}1.52\left(\begin{array}{c}(1.31 \text { to } 1.77) \\
(n=178)\end{array}\right.\end{array}$ & $1.53(1.27$ to 1.84$)$ \\
\hline Bladder (C67) & 615 & $\begin{array}{c}0.99(0.83 \text { to } 1.19) \\
(n=117)\end{array}$ & $1.00(0.85$ to 1.18$)(n=149)$ & $\begin{array}{c}1.14(0.97 \text { to } 1.34) \\
(n=147)\end{array}$ & $\begin{array}{c}1.15(0.93 \text { to } 1.41) \\
(n=92)\end{array}$ & $\begin{array}{c}1.07(0.88 \text { to } 1.30) \\
(n=110)\end{array}$ & $1.09(0.89$ to 1.34$)$ \\
\hline $\begin{array}{l}\text { Non-Hodgkin's lymphoma } \\
\text { (C82-C85) }\end{array}$ & 1509 & $\begin{array}{c}0.99(0.88 \text { to } 1.12) \\
(n=283)\end{array}$ & $1.00(0.90$ to 1.11$)(n=376)$ & $\begin{array}{c}1.07 \begin{array}{c}(0.96 \text { to } 1.19) \\
(n=339)\end{array}\end{array}$ & $\begin{array}{c}1.03(0.90 \text { to } 1.19) \\
(n=204)\end{array}$ & $\begin{array}{c}1.19\left(\begin{array}{c}(1.06 \text { to } 1.34) \\
(n=307)\end{array}\right.\end{array}$ & 1.17 (1.03 to 1.34$)$ \\
\hline Multiple myeloma (C90) & 491 & $\begin{array}{c}0.80(0.64 \text { to } 1.00) \\
(n=76)\end{array}$ & $1.00(0.84$ to 1.19$)(n=127)$ & $\begin{array}{c}1.11(0.92 \text { to } 1.32) \\
(n=118)\end{array}$ & $\begin{array}{c}1.11(0.88 \text { to } 1.40) \\
(n=73)\end{array}$ & $\begin{array}{c}1.16(0.95 \text { to } 1.42) \\
(n=97)\end{array}$ & 1.31 (1.04 to 1.65$)$ \\
\hline Leukaemia (C91-C95) & 635 & $\begin{array}{c}0.71(0.57 \text { to } 0.87) \\
(n=91)\end{array}$ & $1.00(0.86$ to 1.16$)(n=169)$ & $\begin{array}{c}0.97(0.82 \text { to } 1.14) \\
(n=137)\end{array}$ & $\begin{array}{c}1.14(0.93 \text { to } 1.38) \\
(n=99)\end{array}$ & $\begin{array}{c}1.25(1.05 \text { to } 1.48) \\
(n=139)\end{array}$ & 1.50 (1.23 to 1.83$)$ \\
\hline Brain (C71) & 571 & $\begin{array}{c}1.14(0.95 \text { to } 1.38) \\
(n=113)\end{array}$ & $1.00(0.84$ to 1.19$)(n=133)$ & $\begin{array}{c}1.27 \begin{array}{c}(1.08 \text { to } 1.50) \\
(n=143)\end{array}\end{array}$ & $\begin{array}{c}1.19(0.96 \text { to } 1.47) \\
(n=83)\end{array}$ & $\begin{array}{c}1.08(0.88 \text { to } 1.32) \\
(n=99)\end{array}$ & 1.01 (0.81 to 1.26$)$ \\
\hline $\begin{array}{l}\text { All cancers (COO-C97, } \\
\text { excluding }(44)\end{array}$ & 45037 & $\begin{array}{c}0.99(0.97 \text { to } 1.01) \\
(n=8952)\end{array}$ & $\begin{array}{c}1.00(0.98 \text { to } 1.02)(n=11 \\
648)\end{array}$ & $\begin{array}{c}1.01(0.99 \text { to } 1.03) \\
(n=9757)\end{array}$ & $\begin{array}{c}1.04(1.01 \text { to } 1.06) \\
(n=6141)\end{array}$ & $\begin{array}{c}1.12(1.10 \text { to } 1.15) \\
(n=8539)\end{array}$ & $1.12(1.09$ to 1.14$)$ \\
\hline
\end{tabular}

FAR=floating absolute risk; $\mathrm{FCl}=$ floated confidence interval.

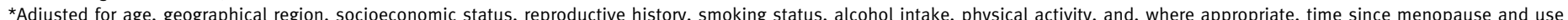
of hormone replacement therapy.

†ICD-0 morphology codes 8140/3, 8144/3, 8145/3, 8260/3, 8480/3, 8481/3, 8490/3.

łICD-0 morphology codes 8070/3, 8071/3, 8072/3, 8074/3.

$\S$ Restricted to never users of hormone replacement therapy. 
of the square indicates the value of the relative risk, and its area is inversely proportional to the variance of the logarithm of the relative risk, providing an indication of the amount of statistical information available for that particular estimate. Results in the text that refer to a specific comparison of two BMI categories or to an estimate of trend are presented in the form of conventional relative risks and their corresponding confidence intervals.

For those cancer sites for which we saw a significant trend of increasing risk with increasing BMI, we estimated the attributable proportions of incident disease in postmenopausal women due to being overweight or obese $(\mathrm{BMI} \geq 25)$ and obese $(\mathrm{BMI} \geq 30)$ by using adjusted estimators of attributable risk that also take account of possible effect modification. ${ }^{4}$ We stratified relative risks of cancer in postmenopausal women used for estimation of attributable risks by smoking status (never smoker, past smoker, current smoker: $<15, \geq 15$ cigarettes/day) and use of hormone replacement therapy (never/past, current). We based estimates of the distribution of postmenopausal UK women within each combination of these factors on the observed distribution within the cohort of women used for these analyses. However, to take account of changes in the average distribution of BMI in UK women of this age that have taken place since the cohort was recruited, we fixed the marginal proportions of women with a BMI of $<25,25-29$, and $\geq 30$ at $30 \%, 39 \%$, and $31 \%$ (on the basis of data in women aged 55-74 from the health survey for England $2004^{2}$ ), and we adjusted the proportions within each combination of factors proportionately. We compared estimates of attributable risk obtained by using the above approach with those obtained from the simpler approach that takes no account of effect modification.

\section{RESULTS}

In total, 1222630 women who had not been registered with a cancer (other than non-melanoma skin cancer) at the time of recruitment and for whom BMI could be calculated were eligible for analysis. Among these women, the average age at recruitment was 55.9 years. During an average follow-up period of 5.4 years for cancer incidence and 7.0 years for cancer mortality, 45037 incident cancers and 17203 deaths from cancer occurred. For some cancers typically associated with a very short survival time - namely, lung, pancreas, and brain cancer - the number of deaths was larger than the number of incident cases because of the slightly longer period of follow-up for mortality than for incidence. When we compared sociodemographic and lifestyle characteristics of women in three broad categories of BMI, we found that BMI was strongly associated with almost all of the characteristics examined (table 1). In particular, women with higher BMI tended to come from a lower socioeconomic class; were less likely to smoke, drink, and use hormone replacement therapy; and had more children than women with lower BMI.
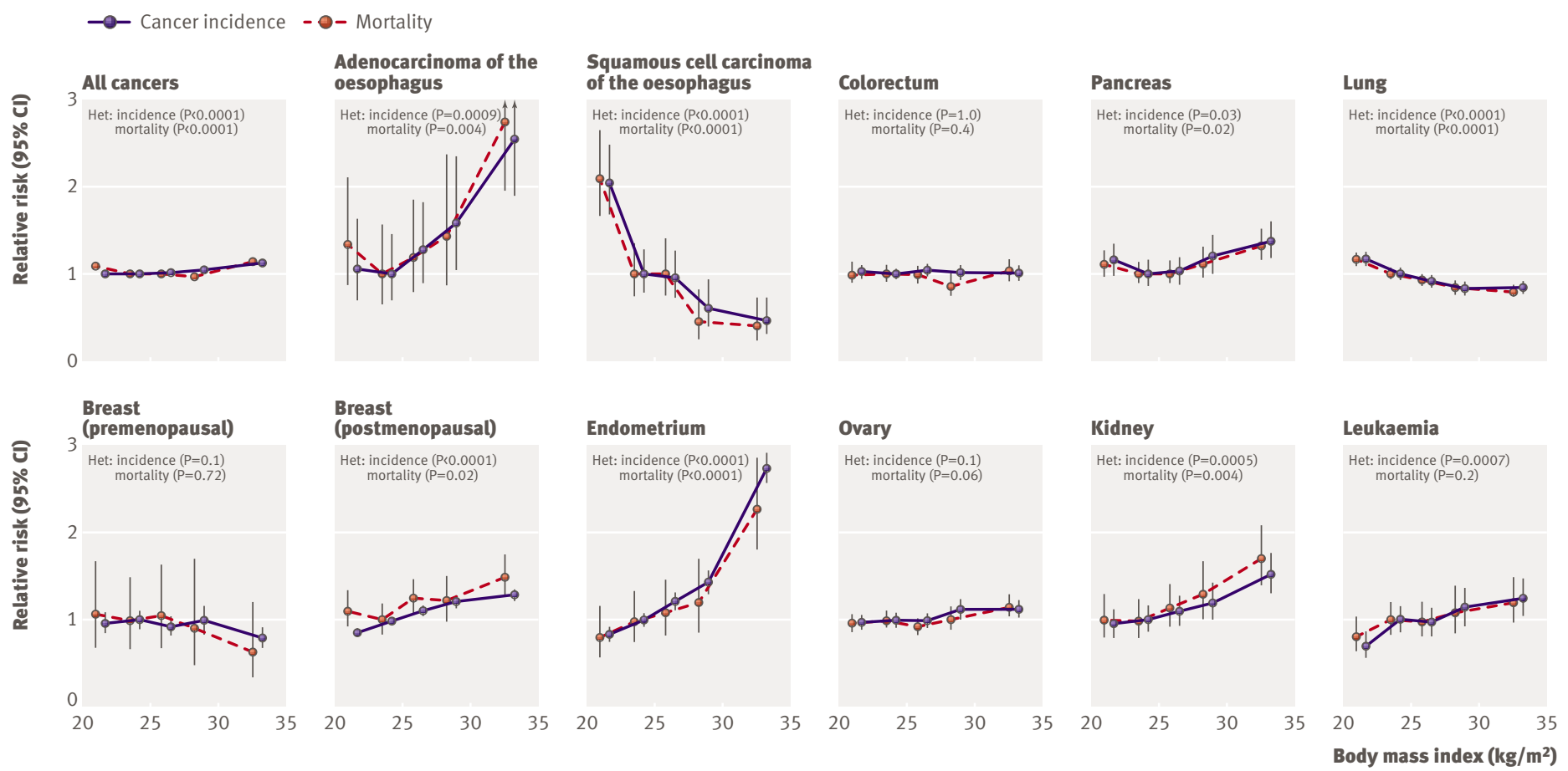

Fig 1 | Relative risk of cancer incidence and mortality for individual cancer sites or types according to body mass index (22.5-24.9=reference group). Adjusted for age, geographical region, socioeconomic status, age at first birth, parity, smoking status, alcohol intake, physical activity, and, where appropriate, time since menopause and use of hormone replacement therapy. Het=test for heterogeneity across categories of body mass index on $\mathrm{df}=4$. *Restricted to never users of hormone replacement therapy 
Table 2 shows the relative risk of cancer incidence for all cancers and for each of the 17 specific sites or types considered, according to BMI, adjusted for age, geographical region, socioeconomic status, age at first birth, parity, smoking status, alcohol intake, physical activity, and, where appropriate, years since menopause and use of hormone replacement therapy. Table 3 shows corresponding relative risks for cancer mortality. The relations between BMI and cancer incidence and mortality for all cancers combined, and for 11 selected sites, are presented graphically in figure 1 .

We found significant heterogeneity in the relative risk of cancer incidence across BMI categories for all cancers $(\mathrm{P}<0.0001)$, adenocarcinoma of the oesophagus $(\mathrm{P}=0.0009)$, squamous cell carcinoma of the oesophagus $(\mathrm{P}<0.0001)$, pancreatic cancer $(\mathrm{P}=0.03)$, lung cancer $(\mathrm{P}<0.0001)$, postmenopausal breast cancer $(\mathrm{P}<0.0001)$, endometrial cancer $(\mathrm{P}<0.0001)$, kidney cancer $(\mathrm{P}=0.0005)$, and leukaemia $(\mathrm{P}=0.0007)$. Although a general test for heterogeneity across the five categories of BMI was not statistically significant for ovarian cancer $(\mathrm{P}=0.1)$, non-Hodgkin's lymphoma $(\mathrm{P}=0.2)$, or multiple myeloma $(\mathrm{P}=0.1)$, a more directed test of linear trend in the log relative risks with increasing BMI was significant for each of these cancers ( $\mathrm{P}=0.02$ for each type of cancer).

For most of the sites that showed significant heterogeneity in risk according to BMI, the relative risk of cancer increased with increasing BMI. The exceptions to this pattern were squamous cell carcinoma of the oesophagus and lung cancer, for which we found trends of decreasing risk with increasing BMI $(\mathrm{P}<0.0001$ in both cases $)$. As lack of physical activity may be causally related to high BMI, we repeated the analyses in tables 2 and 3 without adjustment for physical activity, but the results were essentially unchanged. We also repeated analyses with inclusion of an interaction term for smoking and alcohol status in the model, but this made little difference to the results. Nor did the results change materially when we restricted analyses to women with complete information for all of the adjustment factors.

In general, the patterns for cancer mortality according to BMI were broadly similar to those for cancer incidence, and most cancer sites that showed a significant trend in the relative risk of incidence with increasing BMI also showed a similar trend in the risk of mortality with increasing BMI. For stomach cancer, colorectal cancer, malignant melanoma, cervix cancer, bladder cancer, and brain cancer, we found no significant evidence of any variation in the overall risk of incidence or mortality according to BMI. Analyses of colorectal cancer risk according to subsite yielded similar results for colon cancer (relative risks in BMI categories $<22.5,22.5-24.9$ (reference), 25.0-27.4, 27.5-29.9, and $\geq 30$ were $1.01,1.00,1.03,0.99$, and 1.01$)$ and rectal cancer $(1.04,1.00,1.05,1.06$, and 1.00).

Figure 2 presents, in order of decreasing magnitude, the estimated relative risk of cancer incidence associated with an increase of 10 units in BMI for each individual cancer site or type for all women and within certain subgroups. Based on all women, sites for

\begin{tabular}{|c|c|c|c|}
\hline \multirow[b]{2}{*}{ Cancer site or type } & \multicolumn{3}{|c|}{ All women } \\
\hline & $\begin{array}{l}\text { No of } \\
\text { cases }\end{array}$ & $\begin{array}{c}\text { Relative risk } \\
(95 \% \mathrm{CI}) \\
\text { per } 10 \text { unit } \\
\text { increase in BMI }\end{array}$ & $\begin{array}{l}\text { Relative risk } \\
\quad(95 \% \mathrm{CI})\end{array}$ \\
\hline Endometrium & 2657 & 2.89 (2.62 to 3.18$)$ & - \\
\hline Adenocarcinoma of oesophagus & 150 & 2.38 (1.59 to 3.56$)$ & $\longrightarrow$ \\
\hline Kidney & 723 & $1.53(1.27$ to 1.84$)$ & $=$ \\
\hline Leukaemia & 635 & $1.50(1.23$ to 1.83$)$ & $=$ \\
\hline Breast (postmenopausal)* & 5629 & $1.40(1.31$ to 1.49$)$ & - \\
\hline Multiple myeloma & 491 & 1.31 (1.04 to 1.65$)$ & - \\
\hline Pancreas & 795 & $1.24(1.03$ to 1.48$)$ & 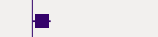 \\
\hline Non-Hodgkin's lymphoma & 1509 & 1.17 (1.03 to 1.34$)$ & - \\
\hline Ovary & 2406 & 1.14 (1.03 to 1.27$)$ & \\
\hline Bladder & 615 & 1.09 (0.89 to 1.34$)$ & + \\
\hline Cervix & 330 & $1.04(0.79$ to 1.38$)$ & $T$ \\
\hline Brain & 571 & 1.01 (0.81 to 1.26$)$ & 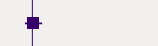 \\
\hline Colorectum & 4008 & $1.00(0.92$ to 1.08$)$ & \\
\hline Malignant melanoma & 1635 & 0.94 (0.82 to 1.07$)$ & $\boldsymbol{\theta}$ \\
\hline Stomach & 521 & $0.90(0.72$ to 1.13$)$ & $\Rightarrow$ \\
\hline Breast (premenopausal) & 1179 & $0.86(0.73$ to 1.00$)$ & E \\
\hline Lung & 3171 & 0.74 (0.67 to 0.82$)$ & \\
\hline \multirow{2}{*}{$\begin{array}{l}\text { Squamous cell carcinoma } \\
\text { of oesophagus }\end{array}$} & 263 & $0.26(0.18$ to 0.38$)$ & \\
\hline & & 0 & $\begin{array}{llll}1 & 2 & 3 & 4\end{array}$ \\
\hline
\end{tabular}

$\begin{array}{ccc}\text { No of } & \begin{array}{c}\text { Relative risk smokers } \\ \text { (95\% Cl) } \\ \text { per } \mathbf{1 0} \text { unit } \\ \text { increase in BMI }\end{array} \\ 1485 & 2.98(2.63 \text { to } 3.39) \\ 53 & 2.99(1.51 \text { to } 5.90) \\ 319 & 1.72(1.30 \text { to } 2.28) \\ 318 & 1.79(1.35 \text { to } 2.38) \\ 2855 & 1.41(1.28 \text { to } 1.55) \\ 253 & 1.25(0.90 \text { to } 1.73) \\ 305 & 1.26(0.94 \text { to } 1.69) \\ 718 & 1.17(0.97 \text { to } 1.42) \\ 1256 & 1.12(0.97 \text { to } 1.30) \\ 206 & 1.02(0.71 \text { to } 1.48) \\ 118 & 0.93(0.58 \text { to } 1.51) \\ 289 & 1.04(0.77 \text { to } 1.42) \\ 1884 & 1.04(0.92 \text { to } 1.18) \\ 891 & 1.02(0.85 \text { to } 1.22) \\ 170 & 0.89(0.59 \text { to } 1.34) \\ 636 & 0.84(0.68 \text { to } 1.04) \\ 269 & 0.82(0.59 \text { to } 1.13) \\ 83 & 0.32(0.17 \text { to } 0.63)\end{array}$

\begin{tabular}{|c|c|c|}
\hline \multicolumn{3}{|c|}{$\begin{array}{l}\text { Excluding first two } \\
\text { years of follow-up }\end{array}$} \\
\hline $\begin{array}{l}\text { No of } \\
\text { cases }\end{array}$ & $\begin{array}{c}\text { Relative risk } \\
(95 \% \mathrm{CI}) \\
\text { per } 10 \text { unit } \\
\text { increase in BMI }\end{array}$ & $\begin{array}{c}\text { Relative risk } \\
(95 \% \mathrm{CI})\end{array}$ \\
\hline 1864 & 2.97 (2.65 to 3.33$)$ & \\
\hline 116 & 2.09 (1.32 to 3.31$)$ & $\longrightarrow$ \\
\hline 526 & $1.56(1.25$ to 1.94$)$ & $\rightarrow$ \\
\hline 447 & 1.48 (1.16 to 1.88$)$ & - \\
\hline 3683 & 1.37 (1.26 to 1.49$)$ & - \\
\hline 354 & 1.17 (0.89 to 1.54$)$ & \\
\hline 563 & 1.28 (1.03 to 1.58$)$ & 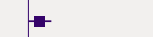 \\
\hline 1035 & 1.28 (1.09 to 1.50$)$ & 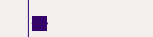 \\
\hline 1629 & $1.10(0.97$ to 1.26$)$ & \\
\hline 381 & $1.06(0.81$ to 1.38$)$ & \\
\hline 189 & 0.95 (0.65 to 1.38$)$ & \\
\hline 399 & $0.92(0.71$ to 1.20$)$ & \\
\hline 2816 & 0.98 (0.89 to 1.09$)$ & \\
\hline 1131 & $0.95(0.81$ to 1.11$)$ & E \\
\hline 349 & $1.08(0.82$ to 1.43$)$ & - \\
\hline 727 & 0.85 (0.70 to 1.04$)$ & $=$ \\
\hline 2257 & 0.77 (0.69 to 0.86$)$ & \\
\hline 189 & 0.31 (0.20 to 0.48$)$ & \\
\hline & & $\begin{array}{llll}1 & 2 & 3 & 4\end{array}$ \\
\hline
\end{tabular}

Fig 2 | Estimated trend in the relative risk of cancer incidence by site or type per 10 unit increase in body mass index (BMI). Adjusted for age, geographical

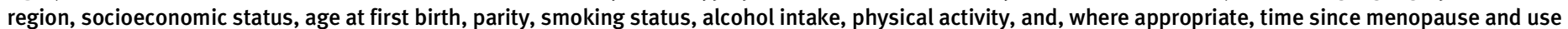
of hormone replacement therapy. *Restricted to never users of hormone replacement therapy 
which we found a significant positive trend in the relative risk of incidence with BMI were endometrial cancer (relative risk per 10 unit increase in $\mathrm{BMI}=2.89,95 \%$ confidence interval 2.62 to 3.18 ), adenocarcinoma of the oesophagus $(2.38,1.59$ to 3.56$)$, kidney cancer $(1.53,1.27$ to 1.84$)$, leukaemia $(1.50,1.23$ to 1.83$)$, postmenopausal breast cancer $(1.40,1.31$ to 1.49$)$, multiple myeloma $(1.31,1.04$ to 1.65$)$, pancreatic cancer $(1.24$, 1.03 to 1.48$)$, non-Hodgkin's lymphoma (1.17, 1.03 to $1.34)$, and ovarian cancer $(1.14,1.03$ to 1.27$)$. The only cancers for which we found a significant inverse association between BMI and cancer incidence were squamous cell carcinoma of the oesophagus $(0.26,0.18$ to $0.38)$ and lung cancer $(0.74,0.67$ to 0.82$)$. We also found evidence of a decrease in the risk of premenopausal breast cancer with increasing BMI $(0.86$,
0.73 to 1.00$)$, although this was of borderline statistical significance $(\mathrm{P}=0.05)$. The trend in the risk of all cancers combined associated with a 10 unit increase in BMI was 1.12 (1.09 to 1.14 ). When we recalculated trend estimates incorporating updated information on BMI from the first re-survey, the results were essentially unchanged.

Most sites that showed a significant association with BMI among all women also showed a similar magnitude of association in never smokers, although the trend estimate in never smokers did not always achieve statistical significance. For lung cancer, the trend among never smokers was non-significant $(0.82$, 0.59 to 1.13 ) and somewhat attenuated compared with that in all women $(0.74,0.67$ to 0.82$)$. For other smoking related cancers (namely, kidney cancer and

\begin{tabular}{|c|c|c|c|c|c|c|c|}
\hline \multirow[b]{2}{*}{ Site (ICD-10 code) } & \multirow[b]{2}{*}{ No of deaths } & \multicolumn{5}{|c|}{ FAR $(95 \% \mathrm{FCl})$ for cancer mortality in women with body mass index $(\mathrm{kg} / \mathrm{m} 2)$} & \multirow[b]{2}{*}{$\begin{array}{l}\text { Trend }(95 \% \mathrm{Cl}) \\
\text { per } 10 \text { units }\end{array}$} \\
\hline & & $<22.5$ & $\begin{array}{c}22.5-24.9 \\
\text { (reference group) }\end{array}$ & $25-27.4$ & $27.5-29.5$ & $\geq 30$ & \\
\hline $\begin{array}{l}\text { Adenocarcinoma of } \\
\text { oesophagus }(\text { (C15) }\end{array}$ & 111 & $\begin{array}{c}1.35(0.87 \text { to } 2.11) \\
(n=20)\end{array}$ & $\begin{array}{c}1.00(0.64 \text { to } 1.57) \\
(n=19)\end{array}$ & $\begin{array}{c}1.21(0.78 \text { to } 1.87) \\
(n=20)\end{array}$ & $\begin{array}{c}1.44(0.87 \text { to } 2.39) \\
(n=15)\end{array}$ & $\begin{array}{c}2.75(1.97 \text { to } 3.85) \\
(n=37)\end{array}$ & 2.24 (1.40 to 3.58 ) \\
\hline $\begin{array}{l}\text { Squamous cell carcinoma } \\
\text { of oesophagus } \ddagger \text { (C15) }\end{array}$ & 182 & $\begin{array}{c}2.10(1.66 \text { to } 2.65) \\
(n=75)\end{array}$ & $\begin{array}{c}1.00(0.74 \text { to } 1.35) \\
(n=44)\end{array}$ & $\begin{array}{c}1.02(0.75 \text { to } 1.40) \\
(n=39)\end{array}$ & $\begin{array}{c}0.45(0.25 \text { to } 0.82) \\
(\mathrm{n}=11)\end{array}$ & $\begin{array}{c}0.42(0.24 \text { to } 0.73) \\
(n=13)\end{array}$ & $0.22(0.14$ to 0.35$)$ \\
\hline Stomach (C16) & 403 & $\begin{array}{c}1.47(1.19 \text { to } 1.81) \\
(\mathrm{n}=92)\end{array}$ & $\begin{array}{c}1.00(0.80 \text { to } 1.24) \\
(n=82)\end{array}$ & $\begin{array}{c}1.16(0.93 \text { to } 1.43) \\
(\mathrm{n}=85)\end{array}$ & $\begin{array}{c}1.34(1.05 \text { to } 1.71) \\
(n=64)\end{array}$ & $\begin{array}{c}1.24(0.99 \text { to } 1.55) \\
(n=80)\end{array}$ & 0.98 (0.76 to 1.26$)$ \\
\hline Colorectum (C18-C20) & 1548 & $\begin{array}{c}1.00(0.90 \text { to } 1.13) \\
(n=302)\end{array}$ & $\begin{array}{c}1.00(0.91 \text { to } 1.10) \\
(n=405)\end{array}$ & $\begin{array}{c}0.98 \text { (0.89 to 1.09) } \\
(347)\end{array}$ & $\begin{array}{c}0.86(0.75 \text { to } 1.00) \\
(n=193)\end{array}$ & $\begin{array}{c}1.03(0.92 \text { to } 1.16) \\
(n=301)\end{array}$ & 0.99 (0.87 to 1.13$)$ \\
\hline Pancreas (C25) & 1130 & $\begin{array}{c}1.11(0.97 \text { to } 1.27) \\
(n=231)\end{array}$ & $\begin{array}{c}1.00(0.89 \text { to } 1.13) \\
(n=267)\end{array}$ & $\begin{array}{c}1.01(0.89 \text { to } 1.15) \\
(n=232)\end{array}$ & $\begin{array}{c}1.12 \text { (0.96 to } 1.31) \\
(n=160)\end{array}$ & $\begin{array}{c}1.32(1.16 \text { to } 1.51) \\
(n=240)\end{array}$ & 1.21 (1.04 to 1.41$)$ \\
\hline Lung (C34) & 3559 & $\begin{array}{c}1.16(1.09 \text { to } 1.24) \\
(n=922)\end{array}$ & $\begin{array}{c}1.00(0.94 \text { to } 1.07) \\
(n=925)\end{array}$ & $\begin{array}{c}0.92 \text { (0.86 to 0.99) } \\
(\mathrm{n}=749)\end{array}$ & $\begin{array}{c}0.84(0.76 \text { to } 0.92) \\
(n=433)\end{array}$ & $\begin{array}{c}0.80(0.74 \text { to } 0.88) \\
(n=530)\end{array}$ & 0.72 (0.66 to 0.79$)$ \\
\hline $\begin{array}{l}\text { Malignant melanoma } \\
\text { (C43) }\end{array}$ & 151 & $\begin{array}{c}1.00(0.69 \text { to } 1.44) \\
(n=29)\end{array}$ & $\begin{array}{c}1.00(0.73 \text { to } 1.37) \\
(n=40)\end{array}$ & $\begin{array}{c}0.95(0.68 \text { to } 1.34) \\
(n=33)\end{array}$ & $\begin{array}{c}0.87(0.56 \text { to } 1.37) \\
(\mathrm{n}=19)\end{array}$ & $\begin{array}{c}1.06(0.73 \text { to } 1.52) \\
(n=30)\end{array}$ & $1.02(0.67$ to 1.56$)$ \\
\hline $\begin{array}{l}\text { Premenopausal breast } \\
\text { (C50) }\end{array}$ & 83 & $\begin{array}{c}1.07(0.68 \text { to } 1.68) \\
(n=20)\end{array}$ & $\begin{array}{c}1.00(0.67 \text { to } 1.50) \\
(n=24)\end{array}$ & $\begin{array}{c}1.05(0.67 \text { to } 1.64) \\
(n=19)\end{array}$ & $\begin{array}{c}0.91(0.49 \text { to } 1.70) \\
(n=10)\end{array}$ & $\begin{array}{c}0.64(0.34 \text { to } 1.21) \\
(n=10)\end{array}$ & $0.68(0.37$ to 1.24$)$ \\
\hline $\begin{array}{l}\text { Postmenopausal breast§ } \\
\text { (C50) }\end{array}$ & 637 & $\begin{array}{c}1.11(0.92 \text { to } 1.34) \\
(n=109)\end{array}$ & $\begin{array}{c}1.00(0.84 \text { to } 1.19) \\
(n=131)\end{array}$ & $\begin{array}{c}1.26(1.07 \text { to } 1.47) \\
(n=147)\end{array}$ & $\begin{array}{c}1.22(0.99 \text { to } 1.49) \\
(n=92)\end{array}$ & $\begin{array}{c}1.49(1.27 \text { to } 1.75) \\
(n=158)\end{array}$ & $1.36(1.12$ to 1.66$)$ \\
\hline Cervix (C53) & 109 & $\begin{array}{c}0.50(0.30 \text { to } 0.86) \\
(n=14)\end{array}$ & $\begin{array}{c}1.00(0.71 \text { to } 1.40) \\
(n=34)\end{array}$ & $\begin{array}{c}0.77(0.51 \text { to } 1.17) \\
(n=22)\end{array}$ & $\begin{array}{c}0.61(0.34 \text { to } 1.11) \\
(n=11)\end{array}$ & $\begin{array}{c}1.15(0.79 \text { to } 1.70) \\
(n=28)\end{array}$ & $1.53(0.95$ to 2.47$)$ \\
\hline Endometrium (C54) & 236 & $\begin{array}{c}0.81(0.57 \text { to } 1.17) \\
(n=30)\end{array}$ & $\begin{array}{c}1.00(0.75 \text { to } 1.33) \\
(n=49)\end{array}$ & $\begin{array}{c}1.09(0.82 \text { to } 1.45) \\
(n=46)\end{array}$ & $\begin{array}{c}1.21(0.85 \text { to } 1.71) \\
(n=32)\end{array}$ & $\begin{array}{c}2.28(1.81 \text { to } 2.87) \\
(n=79)\end{array}$ & 2.46 (1.78 to 3.39$)$ \\
\hline Ovary (C56) & 1651 & $\begin{array}{c}0.96(0.86 \text { to } 1.07) \\
(n=320)\end{array}$ & $\begin{array}{c}1.00(0.91 \text { to } 1.10) \\
(n=439)\end{array}$ & $\begin{array}{c}0.93(0.84 \text { to } 1.03) \\
(n=340)\end{array}$ & $\begin{array}{c}1.02(0.89 \text { to } 1.16) \\
(n=226)\end{array}$ & $\begin{array}{c}1.16(1.04 \text { to } 1.30) \\
(n=326)\end{array}$ & 1.17 (1.03 to 1.33$)$ \\
\hline Kidney (C64) & 382 & $\begin{array}{c}1.01(0.79 \text { to } 1.30) \\
(n=63)\end{array}$ & $\begin{array}{c}1.00(0.80 \text { to } 1.24) \\
(n=81)\end{array}$ & $\begin{array}{c}1.14(0.92 \text { to } 1.42) \\
(\mathrm{n}=80)\end{array}$ & $\begin{array}{c}1.30(1.01 \text { to } 1.68) \\
(n=58)\end{array}$ & $\begin{array}{c}1.71(1.39 \text { to } 2.09) \\
(n=100)\end{array}$ & $1.65(1.28$ to 2.13$)$ \\
\hline Bladder (C67) & 186 & $\begin{array}{c}1.16(0.84 \text { to } 1.60) \\
(n=38)\end{array}$ & $\begin{array}{c}1.00(0.74 \text { to } 1.36) \\
(n=41)\end{array}$ & $\begin{array}{c}1.35(1.02 \text { to } 1.78) \\
(n=49)\end{array}$ & $\begin{array}{c}1.03(0.69 \text { to } 1.54) \\
(n=24)\end{array}$ & $\begin{array}{c}1.12(0.79 \text { to } 1.57) \\
(n=34)\end{array}$ & $1.00(0.68$ to 1.45$)$ \\
\hline $\begin{array}{l}\text { Non-Hodgkin's lymphoma } \\
\text { (C82-C85) }\end{array}$ & 535 & $\begin{array}{c}0.85(0.69 \text { to } 1.04) \\
(n=92)\end{array}$ & $\begin{array}{c}1.00(0.85 \text { to } 1.18) \\
(n=145)\end{array}$ & $\begin{array}{c}0.93(0.78 \text { to } 1.12) \\
(n=118)\end{array}$ & $\begin{array}{c}0.80(0.63 \text { to } 1.02) \\
(n=64)\end{array}$ & $\begin{array}{c}1.10(0.91 \text { to } 1.33) \\
(n=116)\end{array}$ & $1.15(0.92$ to 1.44$)$ \\
\hline Multiple myeloma (C90) & 284 & $\begin{array}{c}0.99 \begin{array}{c}(0.74 \text { to } 1.32) \\
(n=46)\end{array}\end{array}$ & $\begin{array}{c}1.00(0.78 \text { to } 1.28) \\
(n=63)\end{array}$ & $\begin{array}{c}1.26(0.99 \text { to } 1.59) \\
(n=68)\end{array}$ & $\begin{array}{c}1.13(0.82 \text { to } 1.55) \\
(n=38)\end{array}$ & $\begin{array}{c}1.63(1.28 \text { to } 2.08) \\
(n=69)\end{array}$ & $1.56(1.15$ to 2.10$)$ \\
\hline Leukaemia (C91-C95) & 428 & $\begin{array}{c}0.82(0.64 \text { to } 1.04) \\
(n=67)\end{array}$ & $\begin{array}{c}1.00(0.83 \text { to } 1.21) \\
(n=109)\end{array}$ & $\begin{array}{c}0.99(0.81 \text { to } 1.21) \\
(n=93)\end{array}$ & $\begin{array}{c}1.09(0.86 \text { to } 1.39) \\
(n=65)\end{array}$ & $\begin{array}{c}1.21(0.98 \text { to } 1.49) \\
(n=94)\end{array}$ & 1.34 (1.05 to 1.71$)$ \\
\hline Brain (C71) & 645 & $\begin{array}{c}1.17(0.98 \text { to } 1.40) \\
(n=123)\end{array}$ & $\begin{array}{c}1.00(0.85 \text { to } 1.18) \\
(n=143)\end{array}$ & $\begin{array}{c}1.29(1.10 \text { to } 1.51) \\
(n=158)\end{array}$ & $\begin{array}{c}1.18(0.96 \text { to } 1.45) \\
(n=90)\end{array}$ & $\begin{array}{c}1.31(1.10 \text { to } 1.56) \\
(n=131)\end{array}$ & $1.17(0.95$ to 1.43$)$ \\
\hline $\begin{array}{l}\text { All cancers (COO-C97, } \\
\text { excluding }(44)\end{array}$ & 17203 & $\begin{array}{c}1.08(1.05 \text { to } 1.12) \\
(n=3577)\end{array}$ & $\begin{array}{c}1.00(0.97 \text { to } 1.03) \\
(n=4235)\end{array}$ & $\begin{array}{c}1.01(0.98 \text { to } 1.04) \\
(n=3705)\end{array}$ & $\begin{array}{c}0.97 \text { (0.93 to } 1.02) \\
(\mathrm{n}=2250)\end{array}$ & $\begin{array}{c}1.14(1.11 \text { to } 1.18) \\
(n=3436)\end{array}$ & $1.06(1.02$ to 1.10$)$ \\
\hline
\end{tabular}

FAR=floating absolute risk; $\mathrm{FCl}=$ floated confidence interval.

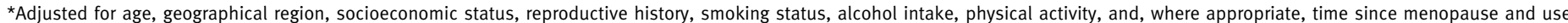
of hormone replacement therapy.

†ICD-0 morphology codes 8140/3, 8144/3, 8145/3, 8260/3, 8480/3, 8481/3, 8490/3.

ҒICD-0 morphology codes 8070/3, 8071/3, 8072/3, 8074/3.

§Restricted to never users of hormone replacement therapy. 
adenocarcinoma of the oesophagus) and for leukaemia, the trend in risk with increasing body mass index became greater in magnitude after restriction to never smokers. The trend in risk per 10 unit increase in BMI for all cancers combined was also slightly greater in never smokers $(1.20,1.15$ to 1.24$)$ than in all women $(1.12,1.09$ to 1.14$)$. When we repeated analyses excluding the first two years of follow-up, the trend estimates were not materially altered.

Figure 3 presents the trend estimates in premenopausal women and postmenopausal never users of hormone replacement therapy for cancer sites with more than 50 cases in women who reported being premenopausal at recruitment. We found significant differences

$\begin{array}{lcc}\text { Cancer site or type } & \begin{array}{c}\text { No of } \\ \text { cases }\end{array} & \begin{array}{c}\text { Relative risk } \\ \text { (95\% Cl) } \\ \text { per 10 unit } \\ \text { increase in BMI }\end{array} \\ \begin{array}{l}\text { Breast } \\ \text { Premenopausal }\end{array} & 1179 & 0.86(0.73 \text { to } 1.00) \\ \text { Postmenopausal } & 5629 & 1.40(1.31 \text { to } 1.49) \\ \chi^{2} \text { for heterogeneity=31.6, } \mathrm{df}=1, \mathrm{P}<0.0001\end{array}$

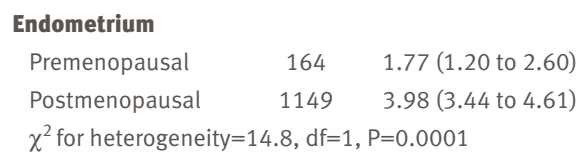

\section{Ovary}

$\begin{array}{lrr}\text { Premenopausal } & 128 & 1.28(0.81 \text { to } 2.00) \\ \text { Postmenopausal } & 982 & 1.12(0.95 \text { to } 1.31) \\ \chi^{2} \text { for heterogeneity }=0.3, \mathrm{df}=1, \mathrm{P}=0.6\end{array}$

Colorectum

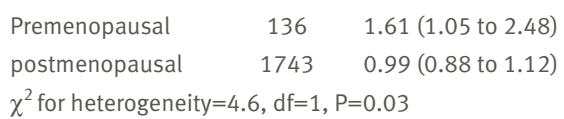

in the trend estimates between premenopausal women and postmenopausal never users of hormone replacement therapy for breast cancer $(\mathrm{P}<0.0001)$, endometrial cancer $(\mathrm{P}=0.0001)$, colorectal cancer $(\mathrm{P}=0.03)$, and malignant melanoma $(\mathrm{P}=0.05)$. For colorectal cancer and malignant melanoma, we found positive trends in risk with BMI in premenopausal women (relative risk per 10 unit increase 1.61 and 1.62), but we found no evidence of any association in postmenopausal never users of hormone replacement therapy (0.99 and 0.92). By contrast, increased BMI was associated with a decreased risk of breast cancer in premenopausal women (relative risk 0.86) and an increased risk in postmenopausal women (1.40). For endometrial cancer, we found a significant increase in risk with increasing BMI for both groups, but the magnitude of the trend was substantially greater in postmenopausal women than in premenopausal women (relative risk 3.98 compared with 1.77). Thus, in total, we found a significant increase in risk with increasing BMI in 10 out of the 17 specific types of cancer considered, including eight sites in which a positive association existed in all women and two sites in which it was confined to either premenopausal women (colorectal cancer) or postmenopausal women (breast cancer).

Table 4 presents (for postmenopausal women only) the proportions of incident cancers attributable to being overweight or obese, and to being obese, for those cancers that showed a significant increase in risk with increasing BMI. The estimated proportion of all cancers attributable to being overweight or obese among postmenopausal women was 5\%. For endometrial cancer and adenocarcinoma of the oesophagus, about a half of cases $(51 \%$ and $48 \%)$ were attributable to being overweight or obese. By comparison, the estimated proportion of cancers attributable to being overweight or obese was between $10 \%$ and $20 \%$ for multiple myeloma, kidney cancer, leukaemia, and pancreatic cancer and below $10 \%$ for all other specific sites or types listed in table 4. Estimates of attributable risk obtained by using unstratified relative risk estimates did not differ materially from those in the table.

\section{DISCUSSION}

In this analysis of 43037 incident cancers and 17203 deaths from cancer among more than 1.2 million women, we found increasing body mass index to be associated with an increased risk of incident and fatal cancer for all cancers combined and for 10 out of the 17 specific sites or types of cancer considered. Although convincing evidence exists of an adverse effect of increased BMI on the risk of several of these cancers, including postmenopausal breast cancer, endometrial cancer, colon cancer, kidney cancer, and adenocarcinoma of the oesophagus, ${ }^{6}$ substantially fewer data exist on the effect of BMI on other cancers. Thus, for many cancer sites, the findings presented here constitute important new evidence. Our data also show that menopausal status is a key factor in the relation between BMI and risk of cancer among cancer sites with at least 50 cases in premenopausal women, by menopausal status at entry in never users of hormone replacement therapy. Adjusted for age, geographical region, socioeconomic status, age at first birth, parity, smoking status, alcohol intake, and physical activity 
women, not only for those cancers that are known to be hormonally related, such as breast and endometrial cancer, but also for other common cancers not generally thought to be mediated by hormones.

\section{Female reproductive cancers}

Among women, hormonally related cancers such as those of the breast and endometrium have been among those most consistently associated with BMI. ${ }^{6}$ The relation between BMI and breast cancer is, however, complicated by the fact that BMI has a different effect on breast cancer risk among premenopausal and postmenopausal women. ${ }^{6}$ Our data confirm this observation, in that the risk of breast cancer among premenopausal women decreases with increasing BMI whereas the risk increases with BMI among postmenopausal women who have never used hormone replacement therapy. The increase in the risk of breast cancer with increasing BMI among postmenopausal women is likely to be due to increased concentrations of circulating sex hormones, and strong empirical evidence exists to support this, ${ }^{13}$ but the opposite relation among premenopausal women is less well understood.

The increased risk of endometrial cancer with increasing adiposity is also thought to be mediated by concentrations of endogenous sex hormones. ${ }^{14}$ Although some studies have examined the risk of endometrial cancer separately among premenopausal and postmenopausal women, they have had relatively few cases among premenopausal women and hence little power to detect an interaction. The substantially greater increase in risk with increasing BMI found here for women who reported being postmenopausal as opposed to premenopausal at recruitment is, therefore, a novel finding. Whereas the effect of obesity on postmenopausal endometrial cancer is thought to be due to increased concentrations of unopposed oestrogens, any effect in premenopausal women may be due to progesterone deficiency rather than an excess of oestrogen ${ }^{14}$; the observed differences in the effect of $\mathrm{BMI}$ on risk by menopausal status may reflect these different mechanisms.

\begin{tabular}{|c|c|c|}
\hline \multirow[b]{2}{*}{ Site or type } & \multicolumn{2}{|c|}{ Proportion (\%) of cancers attributable to body mass index $(\mathrm{kg} / \mathrm{m} 2)$} \\
\hline & $\geq 25$ (overweight or obese) & $\geq 30$ (obese) \\
\hline Endometrial cancer & 51 & 40 \\
\hline Adenocarcinoma of oesophagus & 48 & 35 \\
\hline Multiple myeloma & 18 & 9 \\
\hline Kidney cancer & 15 & 14 \\
\hline Leukaemia & 16 & 9 \\
\hline Pancreatic cancer & 14 & 11 \\
\hline Breast cancer & 7 & 4 \\
\hline Non-Hodgkin's lymphoma & 7 & 6 \\
\hline Ovary & 4 & 3 \\
\hline All cancers & 5 & 4 \\
\hline
\end{tabular}

Data on prevalence of exposure among UK women are based on health survey for England $2004,{ }^{2}$ in which $39 \%$ of women aged $55-74$ had body mass index $25-30$ and $31 \%$ had body mass index $>30$.
Few individual studies have reported a significant effect of adiposity on the risk of ovarian cancer, and the small increase in ovarian cancer risk with increasing BMI found here (relative risk per 10 unit increase in $\mathrm{BMI}=1.14,95 \%$ confidence interval 1.03 to 1.27 ) is consistent with the conclusions of a review of the published evidence. ${ }^{15}$ Some studies have also suggested that the effect of $\mathrm{BMI}$ on ovarian cancer risk is greater in premenopausal women than in postmenopausal women. ${ }^{15-17}$ Our findings with respect to BMI and ovarian cancer in premenopausal and postmenopausal women seem to be consistent with this hypothesis, but, as with previous studies, the numbers of cases among premenopausal women are too few to reliably establish a difference. Thus for cancers of the female reproductive organs, in which the relation with BMI might be expected to be mediated by hormones, the effect of $\mathrm{BMI}$ on risk seems to differ markedly in premenopausal and postmenopausal women.

\section{Other cancers}

Colorectal cancer has been consistently associated with increased adiposity among men. ${ }^{6}$ However, results in women have been less consistent; some studies have reported a positive association, ${ }^{7-20}$ some have reported no association, ${ }^{2122}$ and others have reported greater effects in younger than in older women. ${ }^{23}$ The only previous study that looked at the effect of BMI according to menopausal status found relative risks of colon cancer in obese women compared with nonobese women of 1.88 (1.24 to 2.86) for premenopausal women and 0.73 (0.48 to 1.10$)$ for postmenopausal women $(\mathrm{P}$ value for heterogeneity $=0.01) \cdot{ }^{24}$ Our data show no association between BMI and the overall risk of incidence of or mortality from colorectal cancer among women aged 50-64 at recruitment; however, the effect of increasing BMI on risk does seem to differ between premenopausal and postmenopausal women $(\mathrm{P}$ value for heterogeneity $=0.03)$, with a significant increase in risk with increasing BMI among premenopausal women (relative risk $=1.61,1.05$ to 2.48 ) but not among postmenopausal women $(0.99,0.88$ to 1.12$)$. This apparent interaction between adiposity and menopausal status may explain, at least in part, the variability in published results on the relation between BMI and colorectal cancer among women.

Relatively few studies have reported on the relation between BMI and haematopoietic cancers, and findings have been equivocal regarding BMI in relation to non-Hodgkin's lymphoma, ${ }^{7-192526}$ multiple myeloma, ${ }^{7-18}$ and leukaemia. ${ }^{7-1927}$ Our findings show significant trends of increasing risk with increasing BMI for each type of cancer (relative risk of incidence per 10 unit increase $=1.17,1.31$, and 1.50). Data on the risk of malignant melanoma in relation to BMI have also been inconsistent; some studies have found no evidence of an association in either men or women, ${ }^{7-1928} 29$ some have found an effect in both men and women, ${ }^{30}$ and others have reported an effect in men but not in women. ${ }^{3132}$ Although we found no overall association between BMI and malignant melanoma, the effect of 
BMI on risk seemed to be greater in premenopausal women than in postmenopausal women (relative risk of incidence per 10 unit increase $=1.62 v 0.92 ; \mathrm{P}=0.05)$.

Previous studies of the risk of adenocarcinoma of the oesophagus and kidney cancer in relation to BMI have consistently reported a material increase in risk with increasing BMI, ${ }^{6}$ and our findings provide further support for these associations. Several large cohort studies have also reported an increase in the risk of pancreatic cancer in obese people compared with non-obese people $\mathrm{p}^{7-1933-35}$; estimated relative risks among women ranged from about 1.1 to 1.7. Thus the estimated increase in pancreatic cancer risk reported here (relative risk per 10 unit increase in $\mathrm{BMI}=1.24,1.03$ to 1.48 ) is consistent with these published data.

Two sites for which we found a significant inverse relation between BMI and incidence were lung cancer and squamous cell carcinoma of the oesophagus. Similar findings have been reported previously, ${ }^{73637}$ but these have typically been viewed with caution owing to uncertainty about the extent to which the association between increased risk and low BMI might be due to recent weight loss among people with preclinical disease or residual confounding with smoking or alcohol intake. In our data, the inverse association between BMI and lung cancer was considerably attenuated when we restricted analyses to never smokers; however, the small number of cases of lung cancer among never smokers means that we had insufficient power to exclude an association. By contrast, the substantial inverse association between BMI and squamous cell carcinoma of the oesophagus remained significant after restriction to never smokers (trend in relative risk per 10 unit increase in $\mathrm{BMI}=0.32,0.17$ to 0.63 ), after exclusion of the first two years of follow-up $(0.31,0.20$ to 0.48$)$, and after allowance for a possible interaction between smoking status and alcohol intake. Thus, although we cannot rule out the possibility of residual bias in the relation between BMI and squamous cell carcinoma of the oesophagus, the association seems to be remarkably robust.

\section{Strengths and weaknesses}

The Million Women Study includes one in four UK women who were aged 50-64 during the period of recruitment, making it the largest ever study of women's health. Furthermore, the fact that information on exposure is recorded prospectively ensures that findings are not subject to recall bias. To our knowledge, no previous study has examined the role of BMI in both incidence and mortality of cancer within the same cohort, and this is, therefore, another major strength of the study.

As with most large epidemiological studies, BMI in our cohort was based on self reported height and weight, and although self reported BMI has been shown to be a useful measure of adiposity in epidemiological studies, ${ }^{6}$ it is likely to be subject to both random and systematic errors. The random component of this measurement error is likely to be small, ${ }^{38}$ and indeed adjustment for regression dilution in these analyses had little impact on the dose-response effect. Any systematic error in self reported BMI is likely to stem from a slight over-reporting of height and under-reporting of weight, ${ }^{39}$ leading to an underestimate of BMI. However, the degree of underestimation is proportional to the degree of overweight, ${ }^{40}$ and a validation study of $2500 \mathrm{UK}$ women of a similar age found not only that both measures yielded similar rankings with respect to BMI, with a correlation coefficient of 0.97 , but also that a close numerical agreement existed between self reported $\mathrm{BMI}$ and measured $\mathrm{BMI}{ }^{39}$

For many cancers, weight loss often precedes clinical recognition of the disease and, in affected patients, BMI recorded before diagnosis is an underestimate of their usual BMI. This potential bias, termed reverse causality, can give rise to spuriously increased risks at low levels of BMI. Although exclusion of the first two years of follow-up within these data did not materially affect the findings, the relatively short follow-up period precludes exclusion of longer periods; as reverse causality may exert an influence for as long as 10 years after recruitment, ${ }^{41}$ this is a limitation of the study. Furthermore, we had no information on whether women had lost weight in the year or so before recruitment and so were unable to exclude women whose BMI at recruitment was not necessarily representative of their usual BMI.

Previous publications have suggested a non-linear relation between BMI and mortality, with an increased risk at very low levels of BMI as well as at high levels. ${ }^{4}$ In our data, the numbers of cancers in women with a BMI below 18.5 was extremely small. Furthermore, the relatively short duration of follow-up available here precludes exclusion of the substantial period of follow-up required to minimise the potential effects of reverse causality. ${ }^{541}$ Thus, although we cannot yet answer this question reliably within our cohort, we cannot rule out the possibility of an adverse effect on risk of cancer at extremely low BMI.

In the case of smoking related cancers, residual confounding with smoking history is a key potential source of bias. Few studies have had sufficient power to examine risks reliably in people who have never smoked, but a large study of mortality from cancer found evidence of a greater adverse effect of BMI in never smokers compared with all women for oesophageal cancer, pancreatic cancer, and all cancers (relative risks of any cancer in women with BMI $\geq 40$ compared with women of normal $\mathrm{BMI}=1.88$ and 1.62$).{ }^{7}$ In general, exclusion of smokers from the analyses presented here did not materially alter the findings, although the dose-response estimates became slightly more marked for adenocarcinoma of the oesophagus, kidney cancer, leukaemia, and all cancers combined (relative risk per 10 unit increase in BMI for all cancers $=1.20$ in never smokers compared with 1.12 in all women).

This report focuses on the relation between BMI, measured in middle age, and the short term risk of cancer and death from cancer. It does not consider the role in the development of cancer of other measures of 


\section{WHAT IS ALREADY KNOWN ON THIS TOPIC}

Increased body mass index is known to increase the risk of adenocarcinoma of the oesophagus, endometrial cancer, kidney cancer, and postmenopausal breast cancer in women

Body mass index has also been associated with the risk of other, rarer, cancers, but the findings are not yet conclusive

\section{WHAT THIS STUDY ADDS}

High body mass index in women may increase the risk of multiple myeloma, leukaemia, pancreatic cancer, non-

Hodgkin's lymphoma, and ovarian cancer

Menopausal status seems to affect the relation between body mass index and risk of breast cancer, endometrial cancer, and colorectal cancer

Among postmenopausal women in the UK, $5 \%$ of all cancers (about 6000 annually) are attributable to women being overweight or obese

Around half of all cases of endometrial cancer and adenocarcinoma of the oesophagus in postmenopausal UK women are attributable to women being overweight or obese

body size, such as waist circumference or waist to hip ratio, or indeed measures of BMI at other stages of life such as puberty and young adulthood. Moreover, as some evidence exists to show, for breast cancer at least, that increased BMI at young ages might be associated with a decreased risk in later life,${ }^{42}$ the effects seen here cannot be assumed to apply to BMI measured at other ages.

\section{Attributable risks}

In these data, the great majority $(81 \%)$ of cancers occurred in postmenopausal women, and as considerable differences existed in the effect of BMI on the risk of some cancers according to menopausal status, we confined estimates of attributable risk to postmenopausal women. Although reliably calculating corresponding estimates for premenopausal women on the basis of these data is difficult, the proportion of cancers attributable to being overweight in premenopausal UK women is likely to be less than that for postmenopausal women, because breast cancer is the predominant cancer among premenopausal women and an inverse association exists between BMI and breast cancer risk among such women. On the basis of these results, and current estimates of BMI in postmenopausal women in the UK, we estimate that $5 \%$ of all cancers among postmenopausal women in the UK are attributable to being overweight or obese $(\mathrm{BMI} \geq 25)$ and that $4 \%$ are attributable to obesity (BMI $\geq 30)$. For endometrial cancer and adenocarcinoma of the oesophagus, BMI represents a major modifiable risk factor; as many as about half of all cases of these cancers in postmenopausal women are attributed to being overweight or obese. Overall, these findings imply that 6000 new cancers annually in postmenopausal women in the UK are due to being overweight or obese, of which 4800 are due to obesity.
We thank the women who participated in the Million Women Study and Adrian Goodill for preparation of the figures.

Million Women Study Steering Committee: Joan Austoker, Emily Banks, Valerie Beral, Judith Church, Ruth English, Julietta Patnick, Richard Peto, Gillian Reeves, Martin Vessey, Matthew Wallis.

Million Women Study Coordinating Centre staff: Simon Abbott, Krys Baker, Angela Balkwill, Sue Bellenger, Valerie Beral, Judith Black, Anna Brown, Diana Bull, Delphine Casabonne, Barbara Crossley, Dave Ewart, Sarah Ewart, Lee Fletcher, Toral Gathani, Laura Gerrard, Adrian Goodill, Jane Green, Winifred Gray, Joy Hooley, Sau Wan Kan, Carol Keene, Nicky Langston, Bette Liu, Sarit Nehushtan, Lynn Pank, Kirstin Pirie, Gillian Reeves, Andrew Roddam, Emma Sherman, Moya Simmonds, Elizabeth Spencer, Richard Stevens, Helena Strange, Sian Sweetland, Aliki Taylor, Alison Timadjer, Sarah Tipper, Joanna Watson, Stephen Williams.

Collaborating UK NHS breast screening centres: Avon, Aylesbury, Barnsley, Basingstoke, Bedfordshire and Hertfordshire, Cambridge and Huntingdon, Chelmsford and Colchester, Chester, Cornwall, Crewe, Cumbria, Doncaster, Dorset, East Berkshire, East Cheshire, East Devon, East of Scotland, East Suffolk, East Sussex, Gateshead, Gloucestershire, Great Yarmouth, Hereford and Worcester, Kent (Canterbury, Rochester, Maidstone), King's Lynn, Leicestershire, Liverpool, Manchester, Milton Keynes, Newcastle, North Birmingham, North East Scotland, North Lancashire, North Middlesex, North Nottingham, North of Scotland, North Tees, North Yorkshire, Nottingham, Oxford, Portsmouth, Rotherham, Sheffield, Shropshire, Somerset, South Birmingham, South East Scotland, South East Staffordshire, South Derbyshire, South Essex, South Lancashire, South West Scotland, Surrey, Warrington Halton St Helens and Knowsley, Warwickshire Solihull and Coventry, West Berkshire, West Devon, West London, West Suffolk, West Sussex, Wiltshire, Winchester, Wirral, and Wycombe.

Contributors: All authors participated in the design and conduct of the study and read and approved the final manuscript. GKR and VB are the guarantors. Funding: The Million Women Study is supported by Cancer Research UK, the UK Medical Research Council, and the UK National Health Service breast screening programme. The funders did not influence the conduct of the study, the preparation of this report, or the decision to publish. The authors had full access to all the data in the study and had final responsibility for the decision to submit for publication.

Competing interests: None declared.

Ethical approval: Oxford and Anglia Multi-Centre Research and Ethics

Committee.

Provenance and peer review: Not commissioned; externally peer reviewed.

1 World Health Organization. Obesity: preventing and managing the global epidemic: report of a WHO consultation on obesity, Geneva, 3-5 June 1997. Geneva: WHO, 1998.

2 Department of Health. Health survey for England 2004: updating of trend tables to include 2004 data. London: DH, 2005.

3 Calle EE, Thun MJ, Petrelli JM, Rodriguez C, Heath CW. Body mass index and mortality in a prospective cohort of U.S. adults. N Engl/ Med 1999;341:1097-105.

4 Flegal K, Graubard B, Williamson D, Gail M. Excess deaths associated with underweight, overweight, and obesity. JAMA 2005;293:1861-7.

5 Manson JE, Willett WC, Stampfer MJ, Colditz GA, Hunter DJ, Hankinson SE, et al. Body weight and mortality among women. N Engl J Med 1995;333:677-85.

6 International Agency for Research on Cancer. IARC handbooks of cancer prevention: weight control and physical activity. Lyon: International Agency for Research on Cancer, 2002.

7 Calle E, Rodriguez C, Walker-Thurmond K, Thun M. Overweight, obesity and mortality from cancer in a prospectively studied cohort of US adults. N Engl J Med 2003;348:1625-38.

8 Million Women Study Collaborative Group. The Million Women Study: design and characteristics of the study population. Breast Cancer Res 1999;1:73-80.

9 World Health Organization Expert Committee. Physical status: the use and interpretation of anthropometry. Geneva: WHO, 1995 (WHO technical report series 854 .)

10 Townsend P, Phillimore P, Beattie A. Health and deprivation: inequality and the North. London: Croom Helm, 1988.

11 MacMahon S, Peto R, Cutler J, Collins R, Sorlie P, Neaton J, et al. Blood pressure, stroke, and coronary heart disease: part 1. Prolonged differences in blood pressure: prospective observational studies corrected for the regression dilution bias. Lancet 1990;335:765-74

12 Easton DF, Peto J, Babiker AGAG. Floating absolute risk: an alternative to relative risk in survival and case-control analysis avoiding an arbitrary reference group. Stat Med 1991;10:1025-35. 
13 Key TJ, Appleby PN, Reeves GK, Roddam A, Dorgan JF, Longcope C, et al. Body mass index, serum sex hormones, and breast cancer risk in postmenopausal women. / Natl Cancerlnst 2003;95:1218-26.

14 Key TJ, Pike MC. The dose-effect relationship between "unopposed" oestrogens and endometrial mitotic rate: its central role in explaining and predicting endometrial cancer risk. Br J Cancer 1988;57:205-12.

15 Purdie DM, Bain C), Webb PM, Whiteman DC, Pirozzo S, Green AC Body size and ovarian cancer: case-control study and systematic review (Australia). Cancer Causes Control 2001;12:855-63.

16 Farrow DC, Weiss NS, Lyon JL, Daling JR. Association of obesity and ovarian cancer in a case-control study. Am J Epidemiol 1989;129:1300-4

17 Tornberg SA, Carstensen JM. Relationship between Quetelet's index and cancer of breast and female genital tract in 47,000 women followed for 25 years. Br J Cancer 1994;69:358-61.

18 Wolk A, Gridley G, Svensson M, Nyren O, McLaughlin JK. A prospective study of obesity and cancer risk (Sweden). Cancer Causes Control 2001;12:13-21.

19 Moller H, Mellemgaard A, Lindvig K, Olsen JH. Obesity and cancer risk: a Danish record-linkage study. Eur / Cancer 1994;30:344-50.

20 Martinez ME, Giovannucci E, Spiegelman D, Hunter DJ, Willett WC Colditz GA. Leisure-time physical activity, body size, and colon cancer in women. J Natl Cancer Inst 1997;89:948-55.

21 Pischon $\mathrm{T}$, Lahman $\mathrm{PH}$, Boeing $\mathrm{H}$, Friedenreich $\mathrm{C}$, Norat $\mathrm{T}$, Tjonneland A, et al. Body size and risk of colon and rectal cancer in the European prospective investigation into cancer and nutrition (EPIC). J Natl Cancer Inst 2006;98:920-31.

22 Phillips R, Snowdon D. Dietary relationships with fatal colorectal cancer among seventh-say adventists. J Natl Cancer Inst 1985;74:307-17.

23 Terry P, Giovannucci E, Bergkvist L, Holmberg L, Wolk A. Body weigh and colorectal cancer risk in a cohort of Swedish women: relation varies by age and cancer site. Br J Cancer 2001;85:346-9.

24 Terry PD, Miller AB, Rohan TE. Obesity and colorectal cancer risk in women. Gut 2002;51:191-4.

25 Holly EA, Lele C, Bracci PM, McGrath MS. Case-control study of nonHodgkin's lymphoma among women and heterosexual men in the San Francisco Bay area, California. Am J Epidemiol 1999;150:375-89.

26 Franceschi S, Serraino D, Carbone A, Talamini R, La Vecchia C. Dietary factors and non-Hodgkin's lymphoma: a case-control study in the north-eastern part of Italy. Nutr Cancer 1989;12:333-41.

27 Ross JA, Parker E, Blair CK, Cerhan JR, Folsom AR. Body mass index and risk of leukaemia in older women. Cancer Epidemiol Biomarkers Prev 2004;13:1810-3.

28 Freedman DM, Sigurdson A, Morin Doody M, Sowmya R, Linet MS. Risk of melanoma in relation to smoking, alcohol intake, and other factors in a large occupational cohort. Cancer Causes Control 2003;14:847-57.

29 Veierod MB, Thelle DS, Laake P. Diet and risk of cutaneous malignant melanoma: a prospective study of 50,757 Norwegian men and women. Int J Cancer 1997;71:600-4

30 Gallus S, Naldi L, Martin L, Martinelli M, La Vecchia C; Oncology Study Group of the Italian Group for Epidemiologic Research in Dermatology. Anthropometric measures and risk of cutaneous malignant melanoma: a case-control study from Italy. Melanoma Res 2006;16:83-87.

31 Shors AR, Solomon C, McTiernan A, White E. Melanoma risk in relation to height, weight and exercise (United States). Cancer Causes Control 2001;12:599-606.

32 Thune I, Olsen A, Albrektsen G, Tretli S. Cutaneous malignant melanoma: association with height, weight and body surface area: a prospective study in Norway. Int / Cancer 1993;55:555-61.

33 Patel AV, Rodriguez C, Bernstein L, Chao A, Thun M, Calle EE. Obesity, recreational physical activity, and risk of pancreatic cancer in a large U.S. cohort. Cancer Epidemiol Biomarkers Prev 2005;14:459-66.

34 Michaud DS, Giovannucci E, Willett WC, Colditz GA, Stampfer MI, Fuchs CS. Physical activity, obesity, height, and the risk of pancreatic cancer. JAMA 2001;286:921-9.

35 Samanic C, Chow W-H, Gridley G, Jarvholm B, Fraumeni JF. Relation of body mass index to cancer risk in 362,552 Swedish men. Cancer Causes Control 2006;17:901-9.

36 Kabat GC, Ng SK, Wynder EL. Tobacco, alcohol intake, and diet in relation to adenocarcinoma of the oesophagus and gastric cardia. Cancer Causes Control 1993;4:123-32.

37 Chow WH, Blot WJ, Vaughan TL, Risch HA, Gammon MD, Stanford JL, et al. Body mass index and risk of adenocarcinomas of the esophagus and gastric cardia. J Natl Cancer Inst 1998;90:150-5.

38 Whitlock G, Clark T, Vander Hoorn S, Rodgers A, Jackson R, Norton R, et al. Random errors in the measurement of 10 cardiovascular risk factors. Eur J Epidemiol 2001;17:907-9.

39 Spencer EA, Roddam AW, Key TJ. Accuracy of self-reported waist and hip measurements in 4492 EPIC-Oxford participants. Public Health Nutr 2004;7:723-7.

40 Niedhammer I, Bugel L, Bonenfant S, Goldberg M, Leclerc A. Validity of self-reported weight and height in the French GAZEL cohort. Int J Obes Relat Metab Disord 2000;24:1111-8.

41 Calle EE, Teras LR, Thun MJ. Obesity and mortality. N Engl J Med 2005; 353:2197-9.

42 Magnusson C, Roddam AW. Breast cancer and childhood anthropometry: emerging hypotheses? Breast Cancer Res 2005;7:83-5.

Accepted: 5 October 2007 